\title{
REFLEXIONES SOBRE EL LIBRO ILUSTRADO DEL IMPRESOR FADRIQUE BIEL DE BASILEA*
}

\author{
José Luis Canet Vallés \\ Universitat de València \\ jose.canet@uv.es
}

Cuando se celebró la exposición de El Jardín de Melibea en conmemoración del 500 aniversario de la publicación de la Comedia de Calisto y Melibea en la ciudad de Burgos, se realizó un Catálogo en el que intervinieron diversos especialistas que analizaron múltiples facetas sobre la obra y su época. Julián Martín Abad centró su estudio en el taller del maestro Fadrique Alemán de Basilea, impresor de la Comedia en Burgos ${ }^{1}$. De los tres ejemplares de la Celestina en 16 actos de los que tenemos constancia, este es el único ilustrado con 17 grabados: uno al inicio de cada uno de los Actos (se repite el de los Actos 1 y 5), más el del Argumento inicial, que aparece como portada en el ejemplar conservado en la Hispanic Society of America.

Julián Martín atribuye unos ochenta incunables a este impresor, un buen número de ellos «sin indicaciones tipográficas y en demasiados casos representadas por ejemplares únicos conocidos, a la vez que muy dispersos por la geografía bibliotecaria mundial, lo que dificulta el trabajo del tipobibliógrafo, que continúa siendo muy difícil a pesar de lo ya logrado respecto a los primeros años del siglo XVI...» (p. 66). Con una producción incunable extensa y con un buen número de sus impresos ilustrados, entre ellos diferentes obras maestras de la literatura española: Tractado de amores de Arnalte y Lucenda, Cárcel de Amor, Comedia de Calisto y Melibea, etc., sin embargo, nos recuerda el especialista Martín Abad que «las estampas que encontramos en

${ }^{*}$ Este trabajo se ha realizado dentro del Proyecto de Investigación Parnaseo (Servidor Web de Literatura Española) concedido por el Ministerio de Ciencia e Innovación, referencia FFI2014-51781-P.

${ }^{1}$ Julián Martín Abad, «El taller del maestro Fadrique Alemán de Basilea, vecino de Burgos», en $E l$ jardín de Melibea [catálogo de la exposición]: Monasterio de San Juan, Burgos, 18 de abril 20 de junio de 2000, coord. por Juan Carlos Elorza, Burgos, Monasterio de San Juan, 2000, pp. 47-72. 
los ejemplares de muchas de sus ediciones conocidas constituyen claramente un tema pendiente de estudio» ${ }^{2}$ (p. 70).

Efectivamente, pienso que Fadrique Biel es uno de los impresores de la península que menos atención ha recibido por los especialistas del libro ilustrado. Por ejemplo, James P.R. Lyell en La ilustración del libro antiguo en España, después de analizar los primeros impresos con grabados y los diferentes focos de impresión en la Península (Zaragoza, Valencia, Barcelona, etc.), cuando llega a Burgos alude únicamente el De octo partibus orationis, con la Regula Dominus de Remigius añadida y el Stultiferae naves, de Badius Ascensius. Muy probablemente, como indicaba su autor en 1926, tan solo analiza los ejemplares que posee y a los que ha tenido acceso directamente (ya hemos comentado la dificultad de analizar los impresos de Fradrique Biel por estar dispersos en diferentes bibliotecas europeas y americanas). Francisco Esteve Botey ${ }^{3}$ y Blanca García Vega ${ }^{4}$, prácticamente ni le nombran. Martin $\mathrm{Kurz}^{5}$ informa de la gran profusión de materiales ornamentales en los talleres de Fadrique, y cifra en unos 400 los grabados utilizados hasta 1501, pero sin entrar en pormenores. Antonio Gallego divide la época incunable hispánica en dos etapas, una primera de 1472 a 1490 , en la que reseña los primeros ejemplares estampados, haciendo hincapié en los Trabajos de Hércules de Enrique de Villena, Zamora por Antonio Centenera en 1483; el Espejo de la Cruz, Sevilla por Antón Martínez en 1486, y las Fábulas de Esopo, Zaragoza por Juan Hurus en 1489. En la segunda etapa, que va de 1490 a 1500, comenta que en Castilla el taller «que produce más incunables ilustrados es el burgalés de Fadrique Boel [sic], de Basilea, uno de los más importantes de todo el siglo en España y el que más tipografías diferentes empleó en sus libros. Es el único que puede competir, aunque en desventaja, con el de los Hurus en Zaragoza» ${ }^{6}$. Cita algunos de sus textos más clásicos: el Tratado de amores de Arnalte y Lucenda (1491), del cual refiere que su portada xilografiada todavía es algo rústica; la Cárcel de amor (1496), en donde se imita los grabados

\footnotetext{
${ }^{2}$ Hace referencia a los estudios de: James P. R. Lyell, La ilustración del libro antiguo en España [primera edición: Early Book illustration in Spain, Londres, 1926], edición, prólogo y notas de Julián Martín Abad, Madrid, Ollero y Ramos, 1977, pp. 114-126; Martin Kurz, Handbuch der iberischen Bildricke des XV Jahrhunderts, Leipzig, Karl W. Hiersemann, 1931; e Isabel Mateo, «La temática de la Nave de los Locos en una edición española del siglo xv», en Traza y Baza, 3 (1972), pp. 45-51.

${ }^{3}$ Francisco Esteve Botey, Historia del Grabado, Madrid, ed. Labor, 1993.

${ }^{4}$ Blanca García Vega, El grabado del libro español siglos XV-XVI-XVII, Valladolid, Institución Cultural Simancas, 1984, tomos I y II.

${ }^{5}$ Martin Kurz, Handbuch der iberischen Bildricke des XV Jahrhunderts, ob. cit.

${ }^{6}$ Antonio Gallego, Historia del grabado en España, Madrid, Cátedra, 1979, p. 46. Se basa para estas afirmaciones en los trabajos de Hergueta y Martín, «Los incunables burgaleses», en Boletín de la Comisión Provincial de Monumentos de Burgos, IX (1930) pp. 105 y ss., y XII (1933), pp. 406-409 y 437-441; y F. Vindel, El Arte Tipográfico... vol. VII. Burgos y Guadalajara, Madrid, 1949.
} 
barceloneses; la Suma de confesión de San Antonino (1497) con una bella orla; Stultifera navis (1499) con estampas elegantes que imitan las ediciones nórdicas; la Celestina con 16 grabados, y con 40 la Historia de los nobles caballeros Oliveros de Castilla y Artús d'Algarbe del mismo año. Finalmente afirma que: «Algunas de sus orlas copian las de libros de horas manuscritos, como las estampadas en De octo partibus orationis (1498) con graciosas escenas campestres y de caza; y es muy característica y bella su colección de iniciales xilográficas» (p. 47). Mercedes Fernández Valladares esclarece las relaciones entre el taller de Fadrique con el Cabildo, su importante producción incunable, la crisis de su manufactura a los inicios del siglo XVI, etc. La autora resalta la perfección y variedad de su producción, el gran número de familias de tipos góticos y redondos, y en cuanto al material gráfico explica:

Algo muy parecido sucederá con los materiales ornamentales, pues la inversión en grabados xilográficos realizada en ese último decenio del siglo $\mathrm{xV}$ fue muy notable, encargando estampas no sólo para adornar las portadas sino, en particular, para ilustrar también el interior de los textos con juegos o series de escenas conseguidas por adquisición, préstamo y, fundamentalmente, copia, para lo que los artesanos encargados de entallarlas se sirvieron, a veces de cerca, de modelos de procedencia alemana utilizados por Pablo Hurus en Zaragoza, cuya producción editorial Fadrique de Basilea seguirá también al hilo en frecuentes reediciones -casi como de una sucursal en Castilla del taller aragonés se tratase- ${ }^{7}$.

Intentaré en estas breves páginas analizar una parte de la producción ilustrada de Fadrique Biel, centrándome en aquellos libros de los que he podido conseguir reproducciones aceptables. Ya he comentado antes el número elevado de ejemplares incunables conocidos del impresor afincado en $\mathrm{Burgos}^{8}$, por lo que no me referiré en este estudio a aquellos impresos que no incluyan más de dos xilografías (sin contar las letras iniciales o capitales ni el escudo del impresor). Aunque no puedo dejar de nombrar el Tractado de amores de Arnalte y Luçenda de Diego de San Pedro 9 , primer texto salido de sus prensas con

\footnotetext{
${ }^{7}$ Mercedes Fernández Valladares, La imprenta en Burgos (1501-1560), Madrid, Arco Libros, 2005, vol. I, p. 130.

${ }^{8}$ Se puede listar el número de ejemplares en GW. Database «Union Catalogue of Incunabula». [En línea]. Enlace: <http://www.gesamtkatalogderwiegendrucke.de/GWEN.xhtml> [Consulta: 24/04/2016].

${ }^{9}$ Ejemplar de la Real Academia de la Historia. Hay un manuscrito con diferentes obras de la ficción sentimental, ms. 22021 en la BNM, que incluye el Tractado de Arnalte y Lucenda; pero es posterior a la edición de Burgos de 1491 (se puede consultar una descripción codicológica del manuscrito por Manuel Moreno. [En línea]. Enlace: <http://cancionerovirtual.liv.ac.uk/AnaAdditional/dutton/msdesc/MN53. pdf> [Consulta: 24/04/2016].
} 
portada ilustrada ${ }^{10}$. La estampa xilográfica que ocupa toda la página inicial, al parecer fue tallada ex profeso y está relacionada con el contenido de la obra.

\section{3}

El siguiente libro ilustrado es el de Andrés Li, Repertorio de los tiempos, estampado junto al Lunarium de Bernardo de Granollachs, Burgos, $1493^{11}$. El ejemplar que manejo de la BNM sólo incluye la parte segunda, el Lunarium. En este caso se sigue bastante fielmente el publicado por Pablo Hurus en Zaragoza, 1492, si bien la inclusión de las xilografías de la luna se colocan indistintamente, según le conviene al editor burgalés para completar la página. El Repertorio de los tiempos de Hurus contiene profusión de estampas: unas muestran los signos de los planetas; otras las esferas celestes; los 12 signos del zodíaco y 12 xilografías que representan los meses del año. Finalmente incorpora tres grabados del cuerpo humano de mayor tamaño que relacionan los signos con cada una de sus partes. Imagino que el Repertorio de los tiempos de Fadrique reproduce las mismas estampas que el de Hurus. Pequeños tacos xilográficos de la luna ilustran las páginas del Lunarium en ambos ejemplares, aunque no son exactamente los mismos ni tienen la misma disposición en la página.

\section{6}

La Cárcel de amor, de Diego de San Pedro, salida de los talleres de Fadrique en 1496, es la cuarta edición de las conocidas hasta la fecha y la primera que incluye la Continuación de Nicolás Núñez ${ }^{12}$. La editio princeps corresponde a la de los Cuatro Compañeros Alemanes, Sevilla 1492, sin ilustraciones. Posteriormente vio la luz la impresión zaragozana de Pablo Hurus el

\footnotetext{
${ }^{10}$ Sobre las portadas de los impresos de Fadrique Biel, véase Mónica Morato Jiménez, La portada en el libro impreso español: tipología y evolución, (1472-1558), Tesis doctoral, Universidad Complutense, 2014, pp. 141-168. [En línea]. Enlace: <http://eprints.ucm.es/24482/1/T35151.pdf> [Consulta: 24/04/2016].

${ }^{11}$ Gesamtkatalog der Wiegendrucke. [En línea]. Enlace: <http:/gesamtkatalogderwiegendrucke.de/ docs/LIAND.htm> [Consulta: 24/04/2016]; Haebler 201bis. Más información sobre el Repertorio de Andrés de Li y el Lunario de Granollachs, la edición princeps zaragozana, su adquisición por la BNM, etc., en Josep Lluís Martos, «La editio princeps del Repertorio de los tiempos de Andrés de Li: el proyecto editorial y la recuperación del incunable», en Texto, edición y público lector en los albores de la imprenta, ed. de Marta Haro Cortés y José Luis Canet, Valencia, PUV, 2014, pp. 155-186, quien anota hasta 5 ediciones del Repertorio con el Llunari anteriores a 1500.

${ }^{12} \mathrm{Vid}$. Sun-Me Yoon, «La continuación de Nicolás Núñez a Cárcel de Amor», en Dicenda, 10 (19911992), pp. 327-339.
} 
3 de junio de $1943^{13}$, con 16 xilografías de influencia italiana entre portada e interior de la obra, diseñadas explícitamente para ilustrar el contenido del texto y consideradas como muestras destacadas de los primeros grabadores hispanos ${ }^{14}$, cuyas planchas fueron reutilizadas poco después por Rosenbach en Barcelona el 18 de septiembre del mismo año; tres años más tarde se estampó en Burgos el 27 de octubre de 1496, pero en este caso Fadrique no manejó los mismos tacos, sino copió los grabados con más o menos fidelidad. Remito, en este caso, a los diferentes estudios comparativos de las tres ediciones ilustradas, en los que se puede visualizar perfectamente la evolución y utilización de las estampas por los diferentes impresores ${ }^{15}$.

El libro del Ysopo, famoso fablador, historiado en romançe, publicado por Fadrique Alemán de Basilea el 22 de agosto de 1496, contiene 200 xilografías en 102 folios $^{16}$. No es el primer ejemplar salido de las prensas españolas de esta obra, puesto que en 1482 se estampó por primera vez en el taller de Pablo Hurus y Juan Planck con 125 xilografías ${ }^{17}$; posteriormente en las prensas de Johann Parix y Stephan Clebat en Tolosa, 1488, con 199 grabados; y

${ }^{13}$ Fue descubierta la edición por Miguel Ángel Pallarés en 1994, quien dio la noticia en $L a$ «Cárcel de amor» de Diego de San Pedro, impresa en Zaragoza el 3 de junio de 1493: «membra disjecta» de una edición desconocida, Zaragoza, Centro de Documentación Bibliográfica Aragonesa, 1994. Véase también a María Carmen Marín Pina, «La Cárcel de amor zaragozana (1943), una edición desconocida», en Archivo de filología aragonesa, 51 (1995), Ejemplar dedicado a: In memoriam Francisco Ynduráin (1910-1994), pp. 75-88.

${ }^{14}$ María Rosa Fraxanet Sala, «Estudios sobre los grabados de la novela La Cárcel de Amor de Diego de San Pedro», en Estudios de iconografia medieval española, ed. de Joaquín Yarza Luaces y Lucrecia Herrero, Bellaterra, Universidad Autónoma de Barcelona, 1984, pp. 429-482.

${ }^{15}$ Véase, sobre todo, a Juan Manuel Cacho Blecua, «Los grabados de la Cárcel de Amor (Zaragoza, 1493, Barcelona, 1493, Burgos, 1496): la muerte de Leriano», en Actas del XI Congreso Internacional de la Asociación Hispánica de Literatura Medieval (Universidad de León, 20 al 24 de septiembre de 2005), ed. de Armando López Castro y María Luzdivina Cuesta Torres, León, Universidad, 2007, pp. 142-163. Unos años antes, Alan Deyermond, en «The Woodcuts of Diego de San Pedro's Cárcel de Amor, 14921496», en Bulletin Hispanique, 104-2 (2002), pp. 511-528, también comentó los grabados de las primeras ediciones de la Cárcel. Deyermond planteó que la primera edición (Sevilla 1492) incluiría en su portada un grabado que se utilizaría de nuevo en la edición de Zaragoza 1493, la cual incorporaría quince grabados más, y que los dieciséis totales fueron utilizados a su vez en la traducción catalana (Barcelona 1493) y fielmente copiados en la tercera edición castellana (Burgos 1496). Enrique Fernández Rivera estudia el grabado de Leriano, enfermo de amor, de la edición zaragozana de 1493, y lo relaciona con L'histoire d'Olivier de Castille (Basilea, 1493) que representa a Olivier enfermo de amor por la princesa Hélène, así como posteriormente con la imagen de Calisto pensativo en la cama en la edición burgalesa de la $\mathrm{Ce}$ lestina, en «Calisto, Leriano, Oliveros: tres dolientes y un mismo grabado», en Celestinesca, 36 (2012), pp. 119-142. Véase también en este mismo volumen el artículo de Carmen Parrilla, «Vestir las palabras: grabados xilográficos en la ficción sentimental».

${ }^{16}$ Único ejemplar existente en la Bibliotèque Nationale de France, (digitalizado en Gallica).

${ }^{17}$ Carmen Navarro, «El Incunable de 1482 y las ediciones del Isopete en España», en Quaderni di Lingue e Letterature, 15 (1990), pp. 157-164 y «Notas a la iconografía del Isopete español», en Quaderni di lingue e letterature, 18 (1993), pp. 543-576. Se puede consultar digitalizado en Biblioteca Navarra Digital: BiNaDi. 
una nueva edición zaragozana de Juan Hurus en $1489^{18}$ con 194 ilustraciones. Para Carlos Alvar, Constance Carta y Sarah Finci:

los cuatro ejemplares derivan de un mismo original, que no es otro que la edición bilingüe alemán-latín, que hizo Heinrich Steinhöwel (1411-1479) de las fábulas de Esopo, publicada en Ulm en 1476 o 1477 acompañada de la Vida escrita por Planudes y traducida al latín por Rinuccio d'Arezzo; el libro presentaba, además, 205 xilografías, obras tal vez de Jörg Syrlin el Viejo, escultor de la sillería del coro de la catedral de Ulm en $1474^{19}$.

Para María Jesús Lacarra, el impresor Hurus:

a la hora de seleccionar sus textos en romance, parece seguir de cerca los caminos recorridos por Steinhöwel, ya que en su oficina se imprimen algunos de los libros que este médico humanista había vertido previamente al alemán, como es el caso de la Vida e historia del rey Apolonio, impresa por Juan Hurus hacia 1488, el Espejo de la vida humana de Rodrigo Sánchez de Arévalo, que Steinhöwel había publicado en alemán en 1475 y Hurus lo hace en castellano en 1491, o De las mujeres ilustres en romance, impresa por Hurus en 1494. A la coincidencia de textos se suma la utilización en muchos casos de los mismos, o similares, grabados en madera que Pablo Hurus pudo traerse de sus numerosos viajes por Europa... [En este caso] Hurus consigue una copia fiel, que había preparado el impresor Lienhart Ysenhut cuando editó en Basilea el texto alemán entre 1477-1480, y en la que una parte significativa aparecían invertidos ${ }^{20}$.

M. ${ }^{a}$ Rosario Castelló Benavent, al analizar las ilustraciones del Esopete Ystoriado, observa que tras «hacer un análisis comparativo de las fotocopias de la reproducción en facsímil de la misma [se refiere a la ed. de Pablo Hurus 1489] con la de la ed. de Toulouse de 1488, y tras una observación micrográfica, mediante aparatos de aumento», concluye que ambas corresponden a las mismas planchas ${ }^{21}$. Sobre la edición y los grabados utilizados por Fadrique

\footnotetext{
${ }^{18}$ Ejemplar perteneciente a la Real Biblioteca del Monasterio de San Lorenzo del Escorial.

${ }^{19}$ Carlos Alvar, Constance Carta y Sarah Finci, «El retrato de Esopo en los Isopetes incunables: imagen y texto», en Revista de Filología Española, XCI-2 (2011), pp. 233-260.

${ }^{20}$ «La fortuna del Ysopete en España», en Actas del XIII Congreso Internacional de la Asociación Hispánica de Literatura Medieval (Valladolid, 15-19 de de septiembre de 2009): In Memoriam Alan Deyermond, coordinación de José Manuel Fradejas Rueda, Deborah Anne Dietrick, María Jesús Díez Garretas y Demetrio Martín Sanz, 2010, pp. 107-135; la cita en p. 126. También analiza la evolución del Isopete en: «Las reescrituras de los cuentos medievales en la Imprenta», en IV Congreso Internacional de la Semyr. El texto infinito: reescritura y traducción en la edad Media y el Renacimiento (Barcelona, 5, 6 y 7 de septiembre, 2012), pp. 113-149.

${ }^{21}$ «Aproximación al estudio de las ilustraciones del Isopete ystoriado», en Memorabilia, 5 (2001). [En línea]. Enlace: <http://parnaseo.uv.es/Memorabilia/M5/ArtEsopete.htm\#4> [Consulta: 06/04/2016].
} 
Alemán de Basilea pocos han sido los estudios, excepto el de Carlos Alvar et al., ya citado. En este y otros casos, Fadrique se inspira en las láminas, pero no utiliza los tacos xilográficos de ninguno de los ejemplares anteriores (al menos de los aquí comentados).

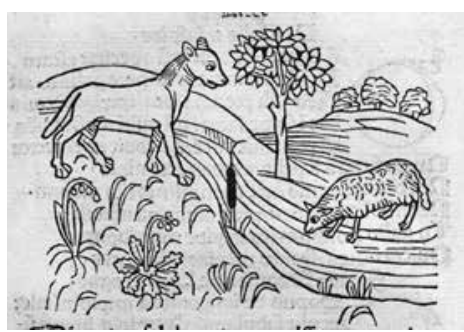

1. Fábula del lobo, Ulm, 1476

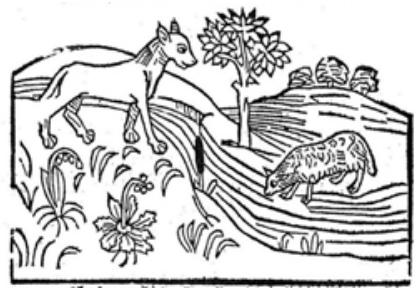

3. Fábula del lobo, Zaragoza, 1489

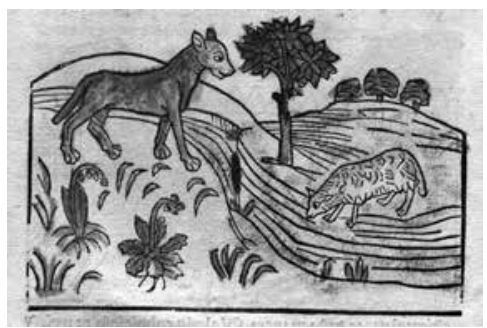

2. Fábula del lobo, Zaragoza, 1482

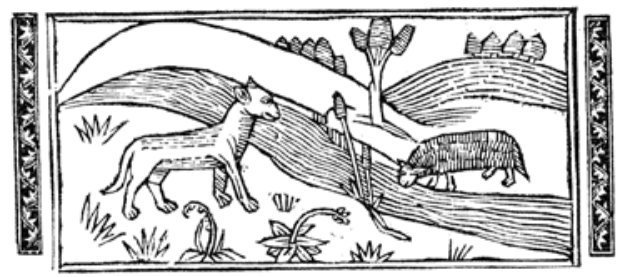

4. Fábula del lobo, Burgos, 1496

\section{7}

De 1497 cabe resaltar el Libro del Anticristo. Sermon del señor san Vicente bienaventurado. El Libro del Judicio postrimero moralizado por Martín Martínez de Ampiés. Las epistolas de Rabbi Samuel embiadas a Rabbi Ysaac con 67 grabados (sin contar la portada, al estar falto el ejemplar); incluye xilografías a página entera después del texto, como colofón religioso a la obra $^{22}$. Es un texto profusamente ilustrado que se ha estudiado poco, posiblemente porque un año antes, en 1496, Paulo Hurus lo había editado con profusión de grabados. Impreso que no he podido manejar, puesto que el ejemplar de la Universidad Complutense ha desparecido ${ }^{23}$, por lo que no he

\footnotetext{
${ }^{22}$ El ejemplar que manejo es el de la BNM; digitalizado en Biblioteca Digital Hispánica. Para el contenido y las traslaciones castellanas, véase María Isabel Toro Pascua, «Las versiones castellanas del sermón Ecce positus est hic in Ruinam, atribuido a San Vicente Ferrer», en Actas del VI Congreso Internacional de la Asociación Hispánica de Literatura Medieval: Alcalá de Henares, 12-16 de septiembre de 1995, ed. de José Manuel Lucía Megías, Alcalá de Henares, Servicio de Publicaciones de la Universidad de Alcalá, 1997, t. II, pp. 1501-1511.

${ }^{23}$ Queda un ejemplar completo de la edición de Hurus, 1496, en la New York Public Library (sign.: ZZ3515); otros incompletos en la British Library y el Escorial. Dio noticia de su desaparición de la Biblioteca de San Isidro de la Universidad Complutense de Madrid en el primer tercio del siglo xx Marta Torres Santo Domingo, en «Sobre la desaparición del incunable El Libro del Antichristo (1496)», en Folio
} 
podido comparar todas las xilografías, excepción hecha de las reproducidas por Marta Torres Santo Domingo procedentes del ejemplar de la New York Public Library.

Paulino Rodríguez Barral propone que las láminas de la edición Der Antichrist, Estrasburgo de ca. 1480-1482, fueron utilizadas por Pablo Hurus en su edición del Anticristo insertas en un marco decorativo ${ }^{24}$. Efectivamente, así es. Por su parte, el impreso burgalés incorpora todas las imágenes (aunque invertidas) de la impresión zaragozana, siendo extraídas mediante copia casi calcográfica por algún tallador burgalés, quien le da la impronta final mediante fondos espaciales sombreados y un doble marco, característicos del taller. En cuanto al texto, Fadrique usa la traducción al castellano de Martín Martínez de Ampiés.

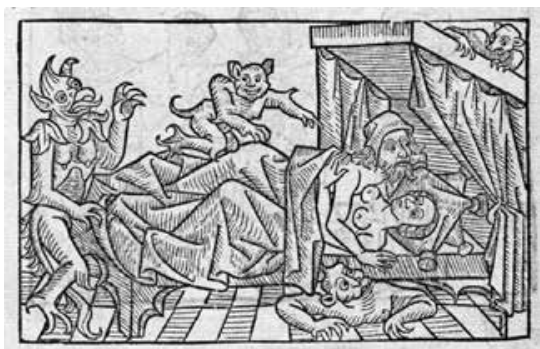

5. Der Antichrist, Estrasburgo, 1482

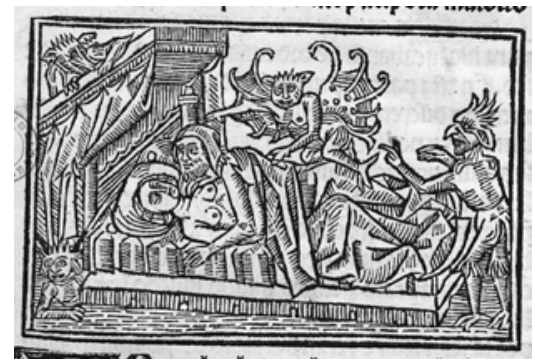

7. Libro del Antichristo, Burgos, Fadrique Biel, 1497

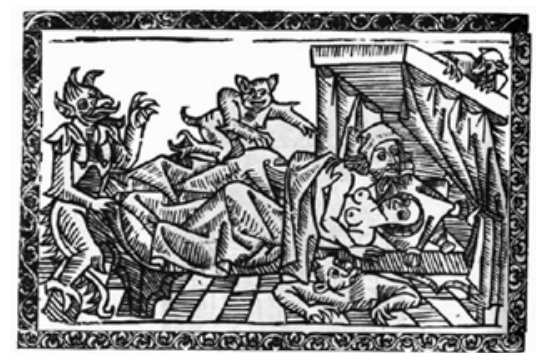

6. Libro del Antichristo (Zaragoza, Hurus, 1496) New York, Public Library

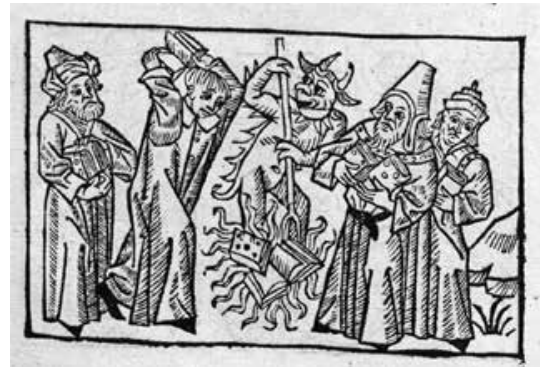

8. Der Antichrist, Estrasburgo, 1482

Complutense, 23 de noviembre de 2009. [En línea]. Enlace: $<$ http://biblioteca.ucm.es/blogs/Foliocomplu tense/955.php\#.VvwXahKLR0s> [Consulta: 03/04/2016]; también de la misma autora: «Algunas notas más sobre el incunable El libro del Antichristo (Zaragoza, Pablo Hurus, 1496)», en Folio Complutense, 8 de abril de 2010. [En línea]. Enlace: <http://biblioteca.ucm.es/blogs/Foliocomplutense/1477.php\#. Vvwa9xKLQ6g> [Consulta: 03/04/2016].

${ }^{24}$ La justicia del más allá. Inconografia en la Corona de Aragón en la baja Edad Media, Valencia, Universitat de València, 2007, p. 116. Del ejemplar Der Antichrist existe versión digitalizada en la Bayerische Staats Bibliothek. [En línea]. Enlace: <http://daten.digitale-sammlungen.de/ db/0002/ bsb00025043/images/> [Consulta: 03/04/2016]. 


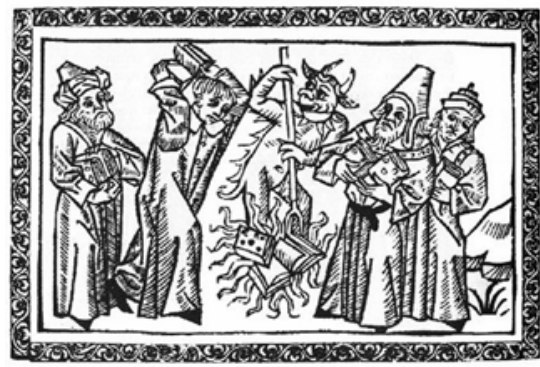

9. Libro del Antichristo (Zaragoza, Hurus, 1496) New York Public Library

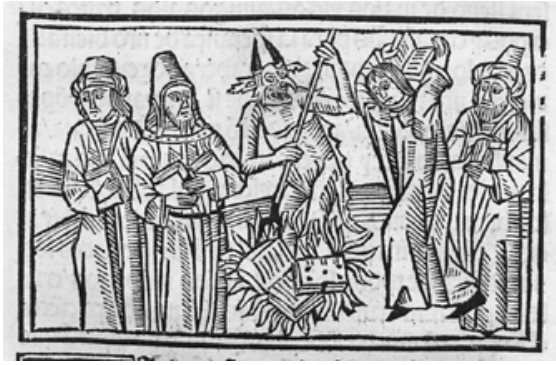

10. Libro del Antichristo, Burgos, Fadrique Biel, 1497

\section{8}

El Exemplario contra los engaños y peligros del mundo, estampado por Fadrique Alemán de Basilea en 1498, es una reedición del texto de Pablo Hurus publicado en 1493 o $1494^{25}$. Existe edición crítica moderna basada en la de Hurus de 1493 que incluye todos sus grabados y aporta, además, diferentes estudios preliminares sobre las transformaciones del Calila en Occidente y las descripciones tipobibliográficas de los ejemplares del siglo xV y XVI conocidos; volumen realizado bajo la dirección de Marta Haro Cortés ${ }^{26}$.

El ejemplar burgalés, como la editio princeps de Hurus ${ }^{27}$, contenía 118 grabados (la copia manejada posee algunas hojas manuscritas que suplen las originales perdidas, lo que hace imposible el recuento exacto); sin embargo, las tarjetas al margen sujetas por una mano indicadora donde se insertan las sentencias en las dos ediciones zaragozanas, se transforman en personajes (de distintos estamentos) que aparentemente dirigen su dedo hacia la sentencia situada en la parte superior ${ }^{28}$. Los tacos tallados para esta impresión burgalesa

${ }^{25}$ Sobre los diferentes ejemplares conservados, tanto de las ediciones de Pablo Hurus de 1493 y 1494 como la de Fadrique Biel (1498), véase a María Jesús Lacarra, «El Exemplario contra los engaños y peligros del mundo y la imprenta zaragozana», en Archivo de Filología Aragonesa, LIX-LX (20032004), pp. 2003-2017 [In memoriam Manuel Alvar (1923-2001), ed. de Rosa M. ${ }^{a}$ Castañer y José M. ${ }^{\mathrm{a}}$ Enguita, Zaragoza, «Institución Fernando el Católico» (CSIC) de la Diputación Provincial de Zaragoza, 2003-2004]; «El Exemplario contra los engaños y peligros del mundo y sus posibles modelos», en Actas del X Congrés Internacional de l'Associació Hispànica de Literatura Medieval, ed. de Rafael Alemany, Josep Lluís Martos y Josep Miquel Manzanaro, Alacant, Institut Interuniversitari de Filologia Valenciana «Symposia Philologica», 2005, 3 vols., II, pp. 929-45.

${ }^{26}$ Exemplario contra los engaños e peligros del mundo. Estudio y edición, dir. de Marta Haro Cortés, Valencia, PUV, Col. Parnaseo, 2007. [En línea]. Enlace: <http://parnaseo.uv.es/Editorial/Exemplario/PortadaParnaseo6.jpg > [Consulta: 05/04/2016].

${ }^{27}$ Los tacos utilizados por Hurus proceden de Konrad Fyner en Urach, donde se editó hacia 14801482 por vez primera la traducción alemana, Das Buch der Beispiele der alten Weisen. Esta era la práctica usual de los Hurus, traer tacos xilográficos de las imprentas alemanas.

${ }^{28}$ Sobre la costumbre de la copia de grabados, y en concreto de estas xilografías de Hurus en el texto 
intentan imitar al máximo las estampas del texto que tienen delante, como así acontece la mayoría de las veces cuando Fadrique Biel de Basilea reedita al poco tiempo libros procedentes de las prensas zaragozanas de los Hurus, lo que llevó a Francisco Vindel a pensar en una estrecha relación comercial entre ambas imprentas ${ }^{29}$. Aunque por mi parte pienso que no es así. Aspecto que retomaré al final de este trabajo. La edición de Hurus embellece los grabados con un marco con cuatro piezas, las dos laterales más estrechas, hasta llegar al ancho exacto de la caja de impresión. Las utilizadas por Fadrique son más anchas, más consistentes, siendo las cuatro piezas del mismo grosor (posiblemente por el ancho de la caja superior). El impresor burgalés imita hasta las grandes capitulares xilografías al inicio de la obra.

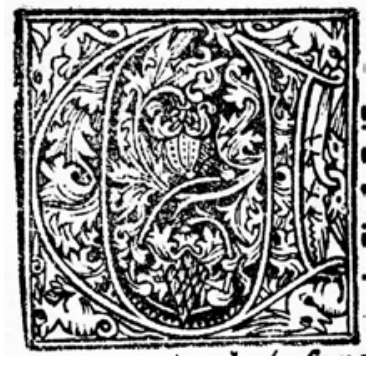

11. Letra C inicial Hurus 1493

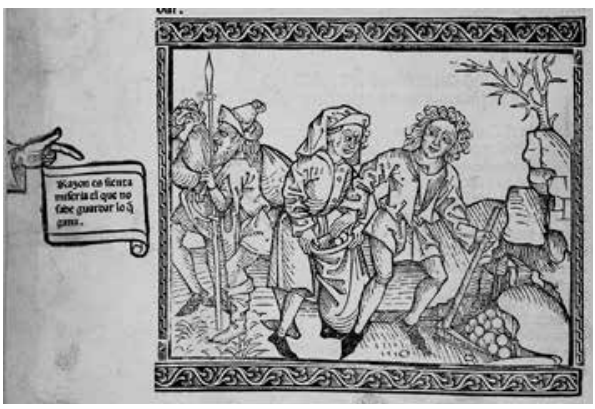

13. Exemplario, Pablo Hurus, 1493

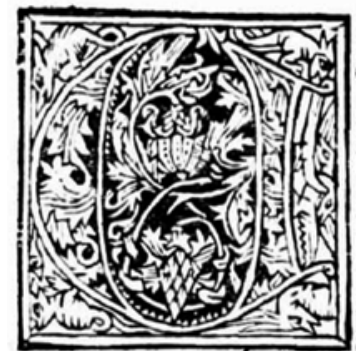

12. Letra C inicial Biel 1498

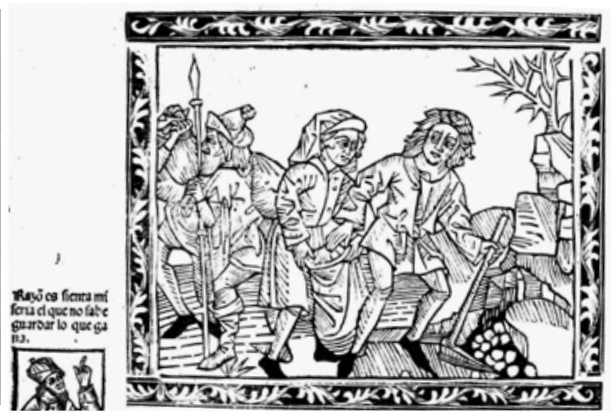

14. Exemplario, Fadrique Biel, 1498

\footnotetext{
burgalés y posteriormente en las imprentas sevillanas de Cromberger, vid. J. M. Aznar Grasa, «Notas sobre el grabado estampado en Zaragoza en los siglos XV y XVI en relación con otros centros impresores de la Península. Tres casos paradigmáticos», en Actas del V Coloquio de Arte Aragonés, Zaragoza, Diputación General de Aragón, 1989, pp. 497-510, especialmente p. 502.

${ }^{29}$ Francisco Vindel, El arte tipográfico en España durante el siglo XV. Tomo VII: Burgos y Guadalajara, Madrid, Dirección General de Relaciones Culturales, 1951, p. xxII.
} 
La historia de los nobles cavalleros Oliveros de Castilla y Artús de Algarbe, 1499, es el primer libro de caballerías de Fadrique Biel ${ }^{30}$. Al parecer, el texto es una traducción bastante libre de la segunda edición de L'ystoire d'Olivier de Castille et d'Artus d'Algarbe, $1492^{31}$. Para José Manuel Lucía Megías, quien realizó una guía de lectura del texto, «el modelo editorial que ve la luz en las prensas burgalesas de Fadrique Biel de Basilea en 1499 se basa en la reedición de Ginebra impresa en 1492, a la que imita no sólo en su disposición tipográfica y letras iniciales sino también en los grabados que acompañan al texto» ${ }^{32}$. Punto de vista que ha sido matizado por Juan Manuel Cacho, para quien:

Tanto el formato utilizado como el número de sus folios apuntan a que el impresor de Basilea pudo utilizar como modelo subyacente un ejemplar de las tres últimas ediciones ginebrinas y no de la segunda edición como postulaba Foulché-Delbosc ${ }^{33}$.

Se refiere a las ediciones de 1493, 1494 y 1495 (si bien los tacos de los grabados son los mismos en las tres ediciones). La edición burgalesa, según Juan Manuel Cacho, destaca por «su cuidada belleza material, a la que contribuyen notablemente sus grandes grabados... la portada xilográfica del Oliveros y 40 de sus grabados interiores están realizados exprofeso, pero Fadrique de Basilea no los vuelve a emplear». Para Mercedes Fernández Valladares ${ }^{34}$ : «las xilografías del Oliveros de Castilla -que no volverán a aparecer en ninguna edición posterior ni de esta obra ni de otra alguna de la imprenta, seguramente porque no eran propiedad del impresor sino del editor o costeador y

${ }^{30}$ Gesamtkatalog der Wiegendrucke 02772. [En línea]. Enlace: <http://www.gesamtkatalogderwiegendrucke.de/docs/GW02772.htm> [Consulta: 05/04/2016]. Existe edición crítica moderna realizada por Ivy Corfis, ed., Historia de Oliveros de Castilla y Artús d'Algarbe, Madison, The Hispanic Seminary of Medieval Studies, 1997.

${ }^{31}$ Miguel Ángel Frontón, «Del Olivier de Castille al Oliveros de Castilla: análisis de una adaptación caballeresca», en Criticón 46 (1989), pp. 63-76; Juan Manuel Cacho Blecua, «De la Histoire d'Olivier de Castille al Oliveros de Castilla: tradiciones y contextos históricos», en Medioevo romanzo, 30:2 (2006), pp. 349-370.

${ }^{32}$ Oliveros de Castilla (Burgos, Fadrique Biel de Basilea, 1499), Guía de Lectura por José Manuel Lucía Megías, Alcalá de Henares, Centro de Estudios Cervantinos, 1998, p. 7. Sigue la opinión de Foulché-Delbosch: «Reseña al facsímil realizado sobre la copia de Huntington», en Revue Hispanique, 9 (2002), pp. 587-595.

${ }^{33}$ Juan Manuel Cacho Blecua, «Los paratextos y contextos editoriales del Oliveros de Castilla (Burgos [Fadrique de Basilea], 1499)», en Formas narrativas breves. Lecturas e interpretaciones, coord. por Carlos Alvar, San Millán de la Cogolla, Cilengua, 2014, pp. 85-124; la cita en p. 95.

${ }^{34}$ «Biblioiconografía y literatura popular impresa: la ilustración de los pliegos sueltos burgaleses (o de babuines y estampas celestinescas)», en eHumanista. Journal of Iberian Studies, 21 (2012), p. 114. 
por ello no pasaron a formar parte del acervo del taller», esta sería una obra de encargo, como posiblemente lo fue el Doctrinal de Cavalleros. El grabado imitado en el epílogo del Oliveros, inexistente en los incunables de Garbin, reproduce la imagen de un escritor sentado ante un atril trabajando, que ya utilizó Fadrique en anteriores ediciones suyas ${ }^{35}$.

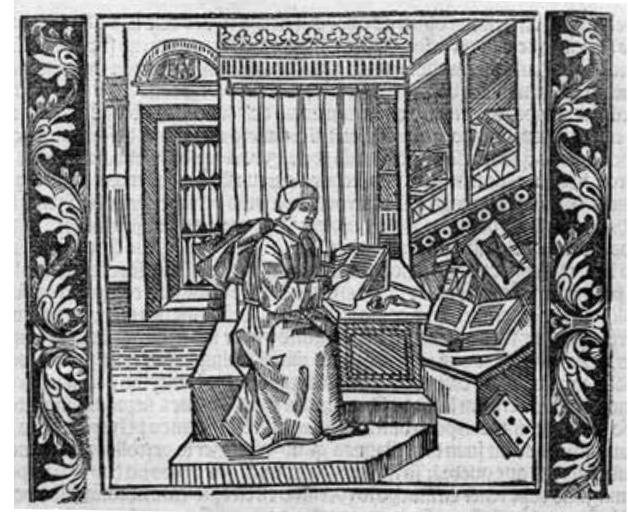

15. Epílogo Oliveros, Burgos, 1499.

Las xilografías de los capítulos siguen el incunable francés, de ahí que se duplique la misma figura en el capítulo $41 \mathrm{y}$ en el 64; todas las entalladuras están colocadas inmediatamente después de la rúbrica de los capítulos, siendo del tamaño de la caja del texto; los 21 primeros se identifican mediante letras del alfabeto correlativas, los otros 19 sin identificación alguna. La xilografía del vuelto de la portada del texto ginebrino-francés que representa a los dos caballeros: Oliveros y Artús, no aparece en la edición de Fadrique de Basilea; la L de la portada imita una xilografía similar a la utilizada en L'histoire des deux nobles chevaliers Valentin et Orson por Jacques Arnollet en Lyon (23 abril de 1495). Pero hay una serie de aspectos que para mí no quedan nada claros. En la edición burgalesa los grabados aparecen invertidos (véanse algunas de las imágenes), como así sucede con el proceso de copia de grabados en la imprenta de Fadrique y que hemos visto anteriormente en otros ejemplares. Pero en este caso han sido modificados de tal manera que no hubiera sido necesario copiarlos directamente del texto francés (para que la reproducción aparezca invertida); cuando se hace una entalladura con

${ }^{35}$ La xilografía había sido utilizada previamente por Fadrique en el Libro del Anticristo de Martínez Ampiés (Burgos, 1497), retomado de un grabado de las comedias de Terencio, impresa en Lyon, por Johannes Treschel en 1493 y posteriormente los incorporó en Donatus, De octo partibus orationis; Remigius, Regula dominus quae pars (1498); Marineus, Epistolae ex antiquorum annalibus excertae (1498) y Homeliae diversorum doctorum in Evangelia dominicalia (1499), etc. 
reminiscencias de otro dibujo existente pero superándolo en calidad, en tamaño, etc., no hace ninguna falta invertir la imagen, que es lo que sucede cuando se reproduce a través de copia mediante calco o papel semistransparente para simplificar el proceso. En este caso pienso que posiblemente algún día aparecerá otro ejemplar del Oliveros al que Fadrique copia directamente.

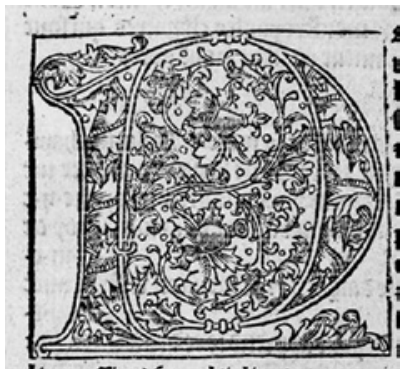

16. Letra capitular Prólogo, Lyon, 1492

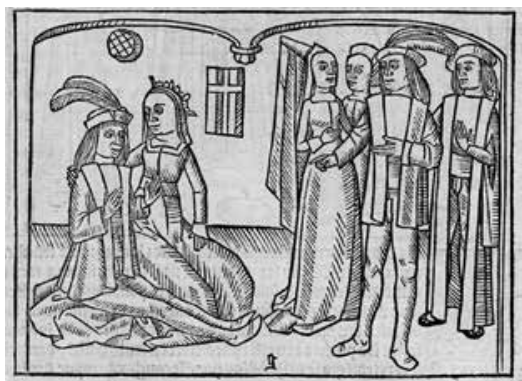

18. L'ystoire d'Olivier, cap. 7, Lyon 1492

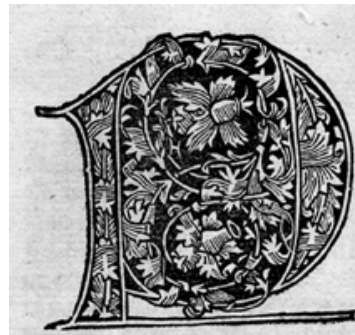

17. Letra capitular Prólogo, Burgos, 1499

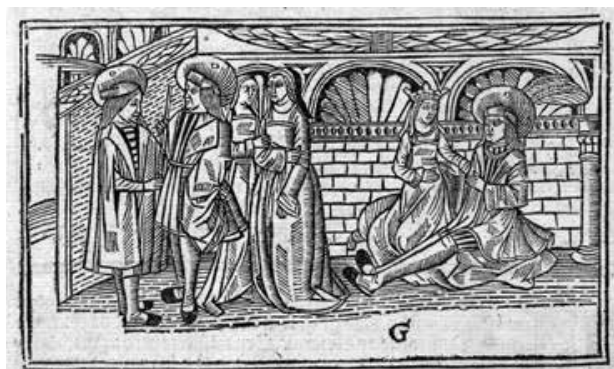

19. Oliveros de Castilla, cap. 7, Burgos 1499

\section{¿1499-1502?}

En este apartado introduzco unos pocos libros de los que desconocemos con exactitud la fecha de impresión, pero que oscilaría en esta franja temporal.

Badius Ascensius, Stultifera naves ${ }^{36}$, [1500?]. El primero que comentó esta edición, dudando de la fecha que aparece en el escudo final del impresor, fue James P.R. Lyell:

De entre los demás libros del siglo Xv de este impresor, realmente el único que merece atención es su hermosa y muy rara edición de Stultiferae naves, de Badius Ascensius, que apareció en 1499, y de la que existe un ejemplar en el

${ }^{36}$ Sobre esta edición perteneciente a la BNM (digitalizada en la Biblioteca Digital Hispana), así como sobre el contenido del texto, tanto el de Sebastián Brant como el de Badius Ascensius, véase Isabel Mateo: «La temática de la nave de los locos en una edición española del siglo XV», en Traza y Baza, 3 (1973), pp. 45-51. 
Museo Británico. Esta obra constituye un complemento al famoso Stultifera navis de Sebastian Brant, pero los libros son diferentes y no deben confundirse. Esta edición española ha sido siempre atribuida al año 1499, presumiblemente porque ese año está grabado en la marca de Fadrique de Basilea, que se encuentra en la última hoja; pero el libro no puede haber sido impreso hasta 1501, o posiblemente más tarde. La primera edición se imprimió en París, a 18 de febrero de 1500 (es decir, 1500-1501) y es idéntica, salvo pequeños detalles, a esta edición de Burgos. Las estampas en la edición francesa son ocho, y seis de ellas se reproducen fielmente en la española. He examinado cuidadosamente ambos libros, y no cabe razonablemente dudar de que los grabados españoles fueron de hecho copiados de los franceses y no al revés. El entallador español ha hecho indudablemente un buen trabajo, pero sin llegar a reproducir completamente los detalles del original (p. 119) ${ }^{37}$.

Pienso que Fadrique sigue la edición de Thelman Kerver de París: Impressit vti primum exciderat: Thielmannus Keruer. Anno hoc iubileo ad. xii. kalendas martias [1500], de la que extraigo las imágenes ${ }^{38}$. No sé Lyell a qué edición parisina se refiere con 8 estampas; esta que manejo contiene el mismo número de entalladuras: seis. Los tacos cincelados por los grabadores de Burgos están muy bien realizados, como se puede comprobar por las imágenes que expongo a continuación, las cuales siguen fielmente el original francés, si bien omiten el número secuencial que incorporan los de la edición de Kerver. Ambos textos incluyen también el escudo de su impresor, muy similares, como colofón.

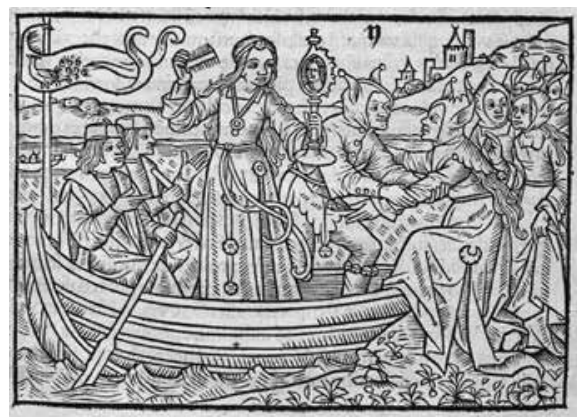

20. Stultiferae Nave, Paris, [1500]

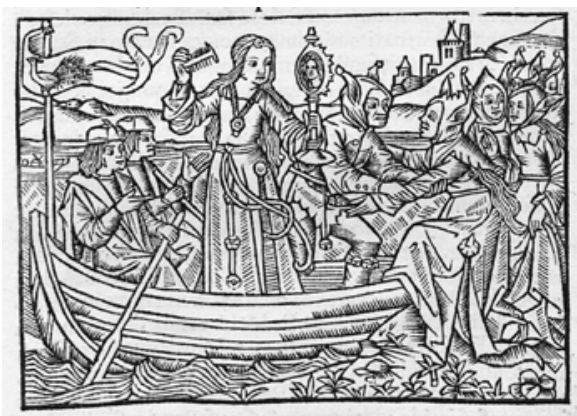

21. Stultiferae Nave, Burgos ¿1500-1501?

${ }^{37}$ James P.R. Lyell, La ilustración del libro antiguo en España (primera edición: Early Book illustration in Spain, Londres, 1926), edición, prólogo y notas de Julián Martín Abad, Madrid, Ollero y Ramos, 1977, p. 119.

${ }^{38}$ Ejemplar de la Bayerische Staats Bibliothek, con reproducción digital. [En línea]. Enlace: $<$ http://

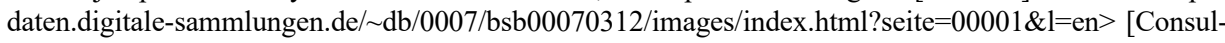
ta: 05/04/2016]. 
La Comedia de Calisto y Melibea, [Burgos, Fadrique Biel, ¿1499-1502?]. Mucho se ha escrito sobre esta obra maestra de la literatura española, desde sus fuentes, género, autoría, ampliaciones, uso de los grabados en obras posteriores ${ }^{40}$, pero sobre todo el análisis de esta edición por considerarla durante muchos tiempo la editio princeps de la Comedia de 16 actos y la primera ilustrada ${ }^{41}$.

${ }^{39}$ Desde hace unos años se ha puesto en duda la fecha que aparece en el colofón de 1499. La presencia de la marca de Fadrique de Basilea al final del texto no sirve para datar la edición de ese mismo año (porque aparece con la misma fecha en ediciones hasta el año de 1502), como ya puso de manifiesto Francisco Vindel, El Arte Tipográfico en España durante el Siglo Xv. VII: Burgos y Guadalajara, Madrid, Dirección General de Relaciones Culturales del Ministerio de Asuntos Exteriores, 195, pp. Xv-XxvI.; y F. J. Norton, La imprenta en España 1501-1520. Edición anotada, con un nuevo «Índice de libros impresos en España, 1501-1520» por Julián Martín Abad, traducción de Daniel Martín Arguedas de la edición original de Cambridge, Cambridge University Press, 1966, Madrid, Ollero \& Ramos, 1997, pp. 209-222. Mercedes Fernández Valladares propone, cuando habla de las marcas tipográficas utilizadas por Fadrique, que «Fue abierta presumiblemente para ser utilizada en el año 1499, aunque no conocemos ninguna edición con colofón de ese año que la muestre, al estar incompletos los pocos ejemplares que conservamos», La imprenta en Burgos (1501-1600), ed. cit., p. 139. El primero que retrasó la fecha de impresión con argumentaciones muy sólidas fue Jaime Moll, «Breves consideraciones heterodoxas sobre las primeras ediciones de La Celestina», en Voz y Letra, 11:1 (2000), pp. 21-25; al que siguieron: Víctor Infantes, «El laberinto cronológico y editorial de las primitivas impresiones de Celestina (1497-1514). Con una Marginalia bibliographica al cabo», en Actas del Simposio Internacional «1502-2002»: Five Hundred Years of Fernando de Rojas' "Tragicomedia de Calisto y Melibea» (18-19 de octubre de 2002, Departamento de Español y Portugués, Indiana University, Bloomington), ed. de Juan Carlos Conde, New York, Hispanic Seminary of Medieval Studies, 2007, pp. 6-9; Julián Martín Abad, Post incunables ibéricos, Madrid, Ollero \& Ramos Editores, 2001, pp. 456-457; Mercedes Fernández Valladares, La imprenta en Burgos (1501-1600), ob. cit., 1 vol. pp. 352-368; y «De la Tipobibliografía a la Biblioiconografía: consideraciones metodológicas para un Repertorio digital de materiales iconográficos de los impresos españoles del siglo XV», en Actas del simposio sobre «El libro en el mundo hispánico: nuevas tendencias y direcciones» (Magdalen College, Oxford, 20-21 de septiembre de 2010), ed. de Juan Carlos Conde y Clive Griffin, New York, Hispanic Seminary of Medieval Studies, 2012 [en prensa]; José Luis Canet, «Introducción» a la Comedia de Calisto y Melibea, ed. crítica, Valencia, PUV - Colección Parnaseo, 2011, pp. 14-15 y sobre todo en pp. 146 y ss., donde retrasa la fecha desde los planteamientos de la crítica textual. Posteriormente, han sido muchos los críticos que han aceptado estas fechas más tardías de 1500-1502.

${ }^{40}$ Véase, sobre todo a Mercedes Fernández Valladares, La imprenta en Burgos (1501-1560), ob. cit., pp. 352-368; y «De la Tipobibliografía a la Biblioiconografía...», art. cit.

${ }^{41}$ Sólo me referiré en este apartado a los trabajos que tienen relación directa con las ilustraciones del texto burgalés: Joseph Snow, «La iconografia de tres Celestinas tempranas (Burgos, 1499; Sevilla, 1518; Valencia, 1514): unas observaciones», en Dicenda: Cuadernos de filología hispánica, 6 (1987), pp. 255280; «Imágenes de la lectura / lectura de las imágenes: El caso de la Comedia burgalesa impresa por Fadrique de Basilea», en Filologia dei Testi a Stampa, ed. de Patrizia Botta, Modena, Mucchi Editore, 2005. 111-29; y recientemente, «Ilustrando Celestina en Celestinesca de 1977 a 2002: Un catálogo», en Celestinesca 39, «Sección especial: La cultura visual de Celestina» (2015), pp. 329-55; Erna Berndt Kelley, «Mute Commentaries on the Text: The Illustrations of the Comedia de Calisto y Melibea», en Fernando de Rojas and 'Celestina': Approaching the Fifth Centenary, ed. de Ivy A. Corfis y Joseph T. Snow, Madison, Hispanic Seminary of Medieval Studies, 1993, pp. 194-227; Clive Griffin, «Celestina's Illustrations», en Bulletin of Hispanic Studies, 78 (2001), pp. 66-68; David Rodríguez-Solás, «A la vanguardia del libro ilustrado: El Terencio de Lyon (1493) y La Celestina de Burgos (1499)», en Bulletin of Spanish Studies, 86:1 (2009), pp. 1-17; John T. Cull, «A Possible Influence on the Burgos 1499 Celestina Illustrations: The German 1486 Translation of Terence's Eunuchus», en La Corónica, 38:2 (2010), pp. 137-60; Enrique Fernández Rivera, «La caída de Calisto en las primeras ediciones ilustradas de La Celestina», en eHumanista, 
Joseph T. Snow, en su ya clásico artículo: «La iconografía de tres Celestinas tempranas...», propuso que entre todos los datos y estudios celestinescos, «sin embargo, se echa en falta una detallada y necesaria historia de su ilustración... El hecho de que la edición de la Comedia de Burgos, a la que generalmente concedemos primacía, venga ilustrada con 17 xilograbados debe ser el primer estímulo a nuestras investigaciones» (p. 256).

Posteriormente, Erna Berndt Kelley, Clive Griffin, David Rodríguez-Solás, John T. Cull, Mercedes Fernández Valladares, etc., consideran que las ilustraciones de la Comedia de Burgos proceden de una reformulación específica pensada para la obra española imitando las entalladuras de las comedias terencianas salidas de las prensas de Lyon o Estrasburgo, años 1493 y 1496, o incluso de la edición del Eunисо de Terencio de 1486.

Veamos algunas de las ilustraciones de las ediciones de Terencio impresas en Ulm por Conrad Dinckmut en $1486^{42}$, en Lyon por Johannes Treschel en 1493 (cuyas xilografías se repetirán en multitud de ediciones posteriores, 1496, 1499, etc. $)^{43}$, y Estrasburgo por Johann Grüninger en $1496^{44}$.

Como se puede comprobar por las imágenes expuestas a continuación, queda bastante explícita la tradición europea de ilustrar las ediciones de Terencio a partir de la comentada por Jodocus Badius Ascensius en los talleres de Treschel en Lyon y posteriormente en Estrasburgo. Pero entre todas las imágenes, excesivamente estáticas, de la tradición francesa y alemana, las que pudieron influenciar directamente a los tallistas hispanos son las que corresponden a los f. XLII v y f. XLIX v de la edición de Estrasburgo de 1496; la segunda de ellas, es la única lámina que aparece sin las clásicas figuras factótum, que serán el modelo de las ilustraciones en gran parte de las ediciones posteriores, sobre todo en España ya como Tragicomedia.

19 (2011), pp. 137-56; Fernando Carmona Ruiz, «La cuestión iconográfica de la Celestina y el legado de Hans Weidizt», en eHumanista, 19 (2011), pp. 79-112; Mercedes Fernández Valladares, «Biblioiconografía y literatura popular impresa: la ilustración de los pliegos sueltos burgaleses (o de babuines y estampas celestinescas)», en eHumanista. Journal of Iberian Studies, 21 (2012), pp. 87-13; Raúl Álvarez-Moreno, «Casa, torre, árbol, muro: hacia una morfología del escenario urbano en las ediciones antiguas de Celestina», en Celestinesca 39, «Sección especial: La cultura visual de Celestina» (2015), pp. 113-36.

${ }^{42}$ Publio Terencio Afer, Eunuchus (en alemán), Ulm, Conrad Dinckmut, 1486. El ejemplar manejado de la Biblioteca Digital de Darmstadt. [En línea]. Enlace: <http:/tudigit.ulb.tu-darmstadt.de/show/ inc-iii-10> [Consulta: 06/04/2016].

${ }^{43}$ Terentii Comoedia sex, a Guidone Juvenale explanatae et a Jodoco Badio, cum annotationis suis, recognitae, Lyon, Johannes Treschel, 1493. El ejemplar manejado pertenece a la Digitale Bibliothek de la Bayersische Staats Bibliothek.

${ }^{44}$ Terenti[us] cu[m] Directorio Vocabulorum Sententiaru[m], Glosa i[n]terlineali artis Comice, Come[n]tariis Donato, Guidone, Ascensio, Argentina (Estrasburgo), Ioanne[m] Grüninger, 1496. Ejemplar de la Real Biblioteca del Palacio Real. El editor Grüninger al menos realizó otra edición en Estrasburgo en 1499 (la Bayersische Staats Bibliothek posee un ejemplar que he manejado, si bien repite los diferentes grabados). 
REFLEXIONES SOBRE EL LIBRO ILUSTRADO DEL IMPRESOR FADRIQUE BIEL DE BASILEA

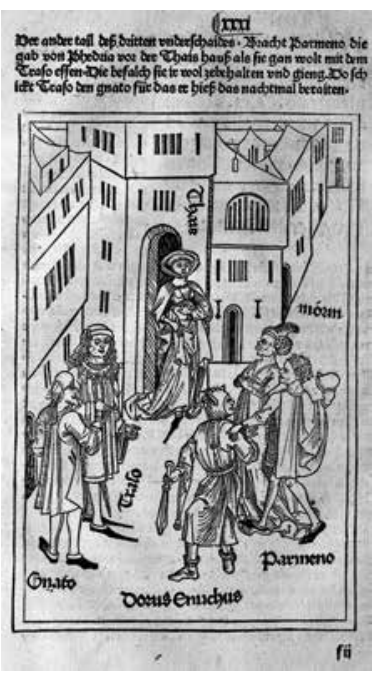

22. Terencio, Eunuchus, 1486, f. fi $\mathrm{r}$

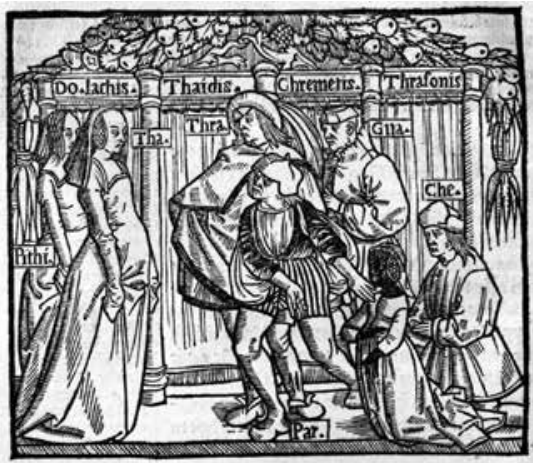

24. Terencio, Lyon, 1493, f. $\mathrm{k}^{\mathrm{iii}} \mathrm{v}$

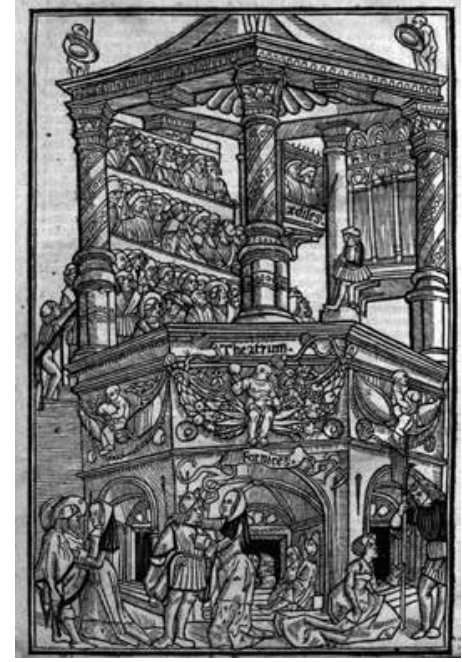

23. Terencio, Lyon, 1493, f. a a $^{\text {iii }}$

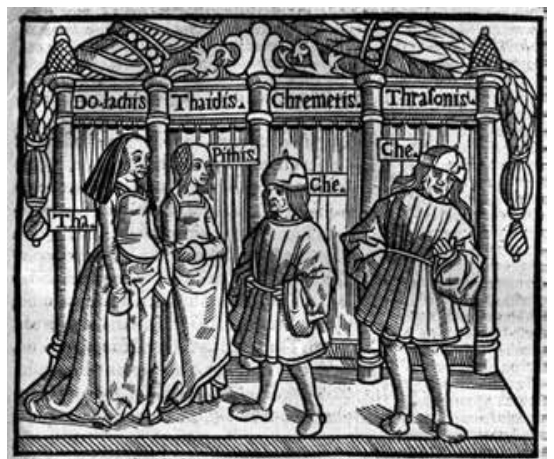

25. Terencio, Lyon, 1493, f. $\mathrm{n}^{\mathrm{i}} \mathrm{r}$

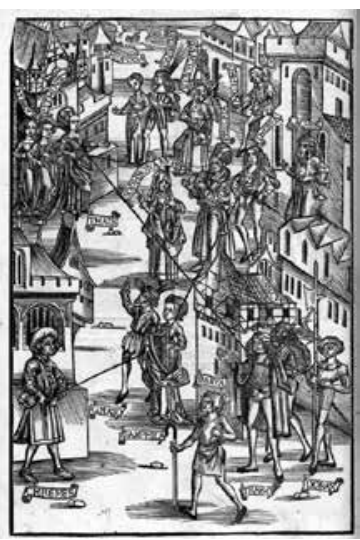

26. Terencio, 1496, Portada Eunuchi f. XXVIII v 


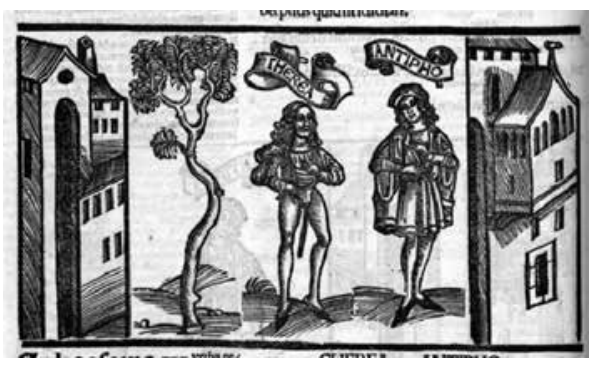

27. Terencio, Estrasburgo, 1496, f. XLII v

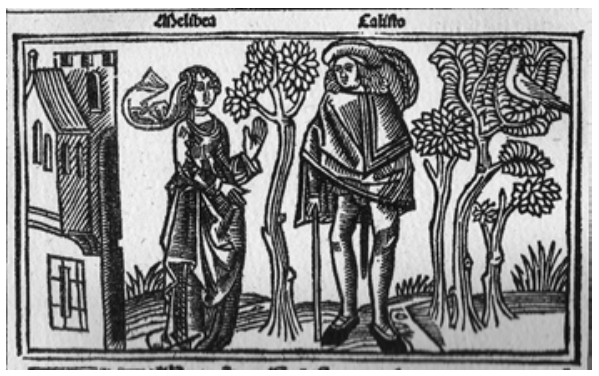

29. Comedia de Calisto y Melibea, Burgos, f. $\mathrm{a}^{\mathrm{j}} \mathrm{r}$

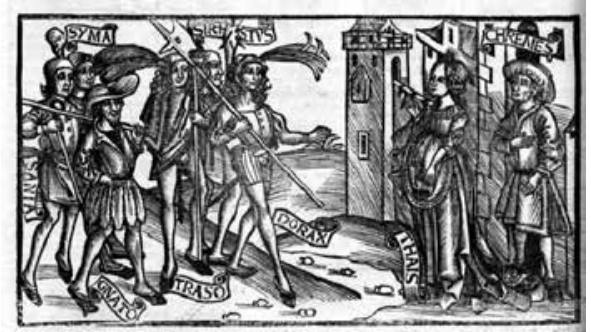

28. Terencio, Estrasburgo, 1496, f. XLIX v

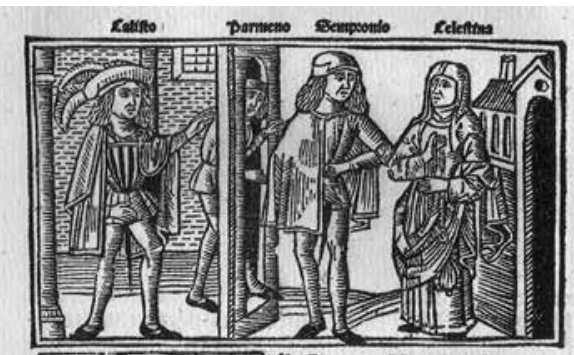

30. Comedia de Calisto y Melibea, Burgos, f. $\mathrm{a}^{\mathrm{j}} \mathrm{v}$

En este caso, las entalladuras incluidas en la edición burgalesa pueden estar influenciadas por alguna de las ediciones terencianas, como han propuesto Erna Berndt Kelley y Clive Griffin al relacionar las casas de las xilografías de la Celestina con los tacos de edificios y árboles de la edición terenciana de 1496 (pero salieron tantas versiones y reimpresiones de las comedias terencianas que podría seguir alguna de las no mencionadas aquí). David Rodríguez-Solás manifiesta que: «Estamos en condiciones de afirmar que Fadrique de Basilea conocía la edición de Lyon y quizás pudo tener en su poder alguna copia de la misma. En 1498 utiliza un xilograbado de un escriba sentado en su estudio para la portada de su edición de De octo partibus Orationis de Elio Donato... Posiblemente el grabador de su imprenta copió directamente del libro ya que la figura aparece invertida, como reflejado por un espejo». Efectivamente así es, como he comentado antes en nota 35, en donde menciono que la xilografía del escriba sentado aparece invertida en varios textos del impresor burgalés. Es la manera de trabajar de sus entalladores mediante copia directa de las ilustraciones de otros textos, bien sean alemanes, franceses o españoles, por medio de algún sistema calcográfico o papel semitransparente, que se traslada posteriormente a la matriz de madera (por lo que muchas veces salen los dibujos como reflejados ante un espejo); posteriormente, el especialista cincelador dará pequeños retoques personales que le identifican: como el uso insistente de sombras paralelas mediante 
líneas muy marcadas en los trajes y paredes de los edificios, sí como el suelo por donde pisan los personajes.

Los grabados xilográficos de la Comedia de Calisto y Melibea, al parecer, fueron realizados exprofeso para cada uno de los Actos de la obra, reflejando, eso sí, los personajes que actúan, no con bandas con su nombre en el interior del grabado, sino en la parte superior, con letra pequeña gótica. Esta letra de $56 \mathrm{~mm}$ es la primera vez que aparece en los impresos del impresor burgalés, y es el motivo por el que Francisco Vindel retrasó la fecha de impresión de la Comedia hasta 1501-1503 ${ }^{45}$. Mercedes Fernández Valladares cree que no es un argumento consistente dado el uso esporádico que se hará en la imprenta de esa tipografía tanto en la etapa post-incunable como después ${ }^{46}$. Pero para mí, sería una de las pocas veces, si no la única, que el impresor Fadrique Alemán de Basilea talle 16 xilografías específicamente diseñadas para una obra literaria sin ser una copia de una edición anterior.

Esta forma de trabajar de Fadrique Alemán de Basilea no es la habitual. Me refiero a la de diseñar ex novo unos grabados xilográficos para ilustrar una obra (el impresor burgalés siempre busca abaratar costes, y el diseño y planificación de una obra con grabados tiene un coste económico y temporal muy superior que si se imita un texto existente y se rellena la forma de impresión casi línea a línea a partir de la cuenta de un original impreso y con espacios para las xilografías preestablecidos). Pienso también que los cinceladores de su taller estaban acostumbrados a copiar de otros libros que tenían delante, bien directamente, bien mediante pequeñas modificaciones, pero conservando los personajes y motivos del modelo. Es por ello que en la década de 1491-1501, exceptuando alguna portada y algún libro específico - Oliveros ${ }^{-47}$, la casi totalidad de las xilografías remiten a otras anteriores (en gran parte procedentes de textos puestos en circulación por los hermanos Hurus). Por todo lo expuesto, pienso que los grabados de la Comedia de Calisto y Melibea imitan los de otra comedia ilustrada anterior, que en estos momentos desconocemos. Hasta ahora han ido apareciendo a lo largo del siglo xx un buen número de ediciones de la Comedia y de la Tragicomedia,

${ }^{45}$ El Arte Tipográfico en España durante el Siglo XV. VII: Burgos y Guadalajara, Madrid, Dirección General de Relaciones Culturales del Ministerio de Asuntos Exteriores, 1995, pp. Xv-XXVI.

${ }^{46}$ «La imprenta gótica burgalesa...», art. cit., pp. 122-123.

${ }^{47}$ Probablemente realizado por encargo, puesto que sus grabados no aparecerán en ningún impreso posterior del taller de Fadrique ni de sus herederos. Vid. Mercedes Fernández Valladares «Biblioiconografía y literatura popular impresa...», art. cit., p. 114; y Juan Manuel Cacho Blecua, «Los paratextos y contextos editoriales del Oliveros de Castilla (Burgos [Fadrique de Basilea], 1499)», en Formas narrativas breves. Lecturas e interpretaciones, coord. por Carlos Alvar, San Millán de la Cogolla, Cilengua, 2014, pp. 85-124; la cita en p. 95. 
pero también de muchas obras literarias en vulgar (que fueron muy buscadas por los libreros y coleccionistas europeos durante los siglos XIX y Xx). Creo, pues, que en algún momento no muy lejano tendremos noticia de otra edición de la Comedia anterior a la de Fadrique Biel (como ya apareció otra previa de la Cárcel de Amor a la impresa en Burgos), que completará el puzle de la génesis de la Celestina.

\section{Reflexiones finales}

1. El número de libros hispanos con al menos varias ilustraciones (sin contar letras capitales) es bastante reducido en la etapa incunable. La mayoría de los impresos destinados a la enseñanza de la gramática y latín, los textos universitarios de las diferentes facultades, etc., no incluyen grabados, exceptuando algunas veces la portada ${ }^{48}$. Tampoco se ilustrarán los libros por encargo de obispos, arzobispos, cabildos y administración civil (como mucho un grabado o dos, normalmente en la portada, verso de la portada y/o colofón $)^{49}$. Obras de devoción popular, libros de viaje a Tierra Santa ${ }^{50}$, textos literarios cortesanos y educativos de la nobleza serán los que se iluminen profusamente, siguiendo en parte la tradición de los manuscritos. En su mayoría ya fueron impresos en otras lenguas europeas con indudable éxito comercial (exceptuando las obras de autores españoles consagrados). Normalmente, en las imprentas europeas e hispánicas, la primera edición de una obra suele aparecer sin xilograbados. Por ejemplo, La primera edición de la Cárcel de amor no estaba ilustrada. Fadrique Biel imita en su Oliveros de Castilla la edición ginebrina de L'ystoire d'Olivier de Castille de 1492 (o las reediciones posteriores de 1493-1494-1495 que incluyen las mismas planchas), pero la primera edición $C y$ commence le

\footnotetext{
${ }^{48}$ Es reveladora la producción de las imprentas salmanticenses, que con 135 incunables contabilizados, únicamente 11 de ellos tienen más de un grabado, y tan solo 2 contienen un número considerable en su interior. En cuanto a la temática, en su mayoría son libros pensados para la Universidad. Vid. José Manuel Aznar Grasa, «La ilustración del libro impreso en Salamanca: Siglos XV y XVI. Análisis cuantitativo y temático», en El libro antiguo español: actas del Segundo Coloquio Internacional (Madrid), coord. por Pedro Manuel Cátedra García, María Luisa López-Vidriero Abello, Salamanca, Ediciones Universidad de Salamanca, 1992, pp. 61-95. Algo similar sucederá con la producción de Fadrique Alemán de Basilea cuando edita obras para la enseñanza (diferentes gramáticas y manuales de aprendizaje del latín) o de encargo (bien sean jurídicas y legislativas o a petición del Cabildo).

${ }^{49}$ Por ejemplo, uno de los libros más editados por encargo para ayudar a los confesores es la Suma de confesión. Defecerunt, de Antonio de Florencia; se realizaron durante el siglo xv, al menos, 9 ediciones en español: Burgos, Friedrich Biel, 1492; 1494 y 1499; Sevilla, Ungut y Polonus, 1492; Zaragoza, Pablo Hurus, 1492, 1497 y 1499, todas ellas sin ilustraciones en el interior.

${ }^{50}$ Véase Federico Delclaux, «Grabados marianos españoles: Incunables (I)», en Scripta (1984), pp. 601-648. [En línea]. Enlace: <http://www.torreciudad.org/fotosbd/instituto_mariologico/scripta_de_maria/1984/web/scripta_1984_delclaux/scripta_1984_delclaux.html > [Consulta: 06/04/2016].
} 
livre de Olivier de Castille et de Artus d'Albarge son tresloyal compaignon, Genève, [Louis Cruse], 1482, no contenía xilograbados; el impresor ginebrino en 1492 justificaba la inclusión de imágenes porque «había obrado a petición de los lectores incluyendo la decoración del texto (hystoire) lo que provocará en los lectores un visible deleite»; lo mismo argumentará Fadrique Biel ${ }^{51}$. En los reinos de Aragón y Castilla, la imprenta que más libros ilustrados puso en el mercado fue la de los hermanos Pablo y Juan Hurus de Zaragoza; estos impresores mantuvieron estrecha relación comercial con mercaderes, tipógrafos y libreros germanos, a los que compraron multitud de planchas que habían adornado obras de indudable éxito comercial; posteriormente las utilizaron en reimpresiones de los mismos textos traducidos al castellano. Fadrique de Basilea también produce un buen número de libros con grabados, si bien copia las estampas de otros existentes en el mercado editorial, en su mayoría originarios de las prensas zaragozanas, pero también, en los últimos años de la década de los noventa, de los procedentes de Lyon y París (Oliveros de Castilla, Stultiferae Naves, y probablemente las comedias de Terencio que sirvieron de inspiración para la Celestina).

2. El libro ilustrado salido de las prensas de Fadrique Alemán de Basilea, como le gustaba firmar sus libros, es de escasísima originalidad. El impresor burgalés, si bien poseía una amplia familia de letrerías (góticas y redondas) y ponía gran esmero en la compaginación de sus textos, sin embargo contaba con unos entalladores y cinceladores que no destacaron por sus creaciones. Tan solo algunas portadas y los grabados de la Comedia de Calisto y Melibea (16 xilografías) parecen haberse diseñado ex novo. Y para mí existen dudas de que las ilustraciones de la Celestina sean originales y talladas ex profeso, pues sería un caso único en su trayectoria como impresor (como hemos podido comprobar a lo largo de este artículo). Además, los estudios tipobibliográficos y estemáticos sobre la Comedia de Calisto y Melibea parecen demostrar que es un texto posterior a 1499 (más bien de los años 1500-1502), lo que daría pie a que fuera la segunda edición ilustrada ${ }^{52}$.

${ }^{51}$ «A cuyo ruego, y por el general provecho, fue transladada de francés en romance castellano y emprimida con mucha diligencia, y puesto en cada capítulo su historia [se refiere a las imágenes, como se indica en el texto francés], porque fuesse más frutuosa e aplazible a los lectores e oidores», Juan Manuel Cacho Blecua, «La configuración iconográfica de la literatura caballeresca: el Tristán de Leonís y el Oliveros de Castilla (Sevilla, Jacobo Cromberger)», en Letras, 50-51 (2004-2005), pp. 51-80.

${ }^{52}$ Véase José Luis Canet, «Introducción» a la Comedia de Calisto y Melibea, Valencia, Publicacions Universitat de València, col. Parnaseo, 2011, pp. 97-149; y «A vueltas con las ediciones de la Comedia de Calisto y Melibea», en Texto, edición y público lector en los albores de la imprenta, ed. de Marta Haro Cortés y José Luis Canet, Valencia, Publicacions de la Universitat de València, 2014, pp. 53-82. 
3. Esta ligazón de Fadrique Biel con los textos zaragozanos ha dado pie a la creencia de que tenía relaciones estrechas con el taller de los Hurus ${ }^{53}$. Pienso, después de lo hasta aquí analizado (habría que ampliar con otros ejemplares no iluminados procedentes de estas dos manufacturas), que el impresor burgalés copia descaradamente aquellos libros que le parecen interesantes y con posibilidades de venta, pero sin comprar las planchas xilográficas (las cuales tallará de nuevo y las reutilizará en otros textos con posterioridad); justo lo contrario de lo que hacía Pablo Hurus, quien adquiría tacos de libros ilustrados alemanes y efectuaba la traducción del texto al castellano; o como lo hizo Rosenbach en Barcelona con la edición al catalán de la Cárcel de Amor. En estos últimos casos hay una relación comercial clara, pues se utilizan los mismos tacos xilográficos (una manera de amortizar el gasto tanto para el editor original como para el reimpresor). Pero estas actuaciones se suelen dar cuando la obra en cuestión se traslada de una lengua a otra y el impreso resultante no entra en competencia directa en el mismo ámbito comercial. En el taller de Fadrique Biel se tallan de nuevo los tacos, copiados en su inmensa mayoría de forma directa sobre el ejemplar que se imita (de ahí las inversiones especulares de muchos de los grabados) y se editan las obras poco tiempo después, con lo que la competencia sería atroz. Sobre todo porque Fadrique abarata el coste de producción y por tanto el de venta posterior (realizar una copia de un taco xilográfico es mucho más económico que el diseño original completo); pero también porque amplía la caja de impresión e incluye algo más de texto por plana, reduciendo así el número total de pliegos de la obra. Un ejemplo: la Cárcel de amor de Fadrique incluye la Continuación de Nicolás Núñez; repite más veces los grabados en su interior, y tan solo aumenta medio pliego la edición de Rosenbach (que probablemente tuviera los mismos folios que la de Hurus). Todo ello sin contar el transporte para vender los ejemplares en las ferias castellanas ${ }^{54}$. En este caso no considero que hubiera una buena relación entre ambos impresores. Pero como cada uno de ellos vivía en un reino

\footnotetext{
${ }^{53}$ Véase Francisco Vindel, El Arte Tipográfico... vol. vII, ed. cit., pp. XXII-XXIII.

${ }^{54}$ Sobre el comercio de los libros en Zaragoza en la época incunable así como el mercado natural de los impresores hacia las ferias de Castilla, es imprescindible el estudio de Miguel Ángel Pallarés Jiménez, La imprenta de los incunables de Zaragoza y el comercio internacional del libro a finales del siglo XV, Zaragoza, Diputación de Zaragoza, Institución Fernando el Católico, 2003, en donde se relacionan diferentes contratos de Pablo Hurus con mercaderes de libros para el envío y venta en Medina y Valladolid. Muy probablemente en estas fechas los libros todavía continuaban exentos de algunos de los impuestos: almojarifazgo y alcabalas, que gravaban el traslado de las mercancías de un estado a otro, como al parecer se aprobó en las Cortes toledanas de 1480. Vid. Elisa Ruiz García, «Una aproximación a los impresos jurídicos castellanos (1480-1520)», pp. 311-312. [En línea]. Enlace: <https://www.ucm.es/data/cont/docs/4462013-08-22-13\%20aproximacion.pdf $>$ [Consulta: 06/04/2016]. La ferias de Medina y Valladolid eran «francas», que no tenían que pagar a las Haciendas reales impuestos por transacciones mercantiles.
} 
diferente (Aragón y Castilla), no habían posibilidades legales para controlar las copias ni reediciones; dependía únicamente de la visión comercial de los editores (y en este caso no sé si el propio Fadrique vendía sus libros en las ferias de Valladolid y Medina -como lo hacía Hurus- o si poseía librería en Burgos, o por el contrario trabajaba para un librero avispado).

4. En los últimos treinta años los estudios sobre los talleres e impresores de la Península ibérica han aumentado sustancialmente, por lo que tenemos una mejor visión sobre la producción del libro, distribución y venta. Sin embargo, todavía nos quedan muchas lagunas. En el caso de Fadrique Alemán de Basilea queda mucho por esclarecer. Que yo sepa desconocemos si tuvo o no una librería que acompañara su taller de impresión; si era él quien invertía el dinero para la edición de los textos, o por el contrario había libreroseditores que le encargaban el trabajo (todo ello sin contar con las obras por encargo del Cabildo u otras instituciones civiles y religiosas). No es lo mismo apostar en el mercado editorial por un libro ilustrado original con una inversión económica muy elevada (diseño de las imágenes originales en relación con la obra; tamaño específico de las xilografías para la caja de impresión; cuenta del original dejando espacios para las ilustraciones, etc.), que cuando se imita un libro existente, con un coste mucho menor, tanto por el cincelado de los grabados como por la composición de las formas, amén de conocer la aceptación por los lectores. Al parecer Fadrique Biel y los libreros-comerciantes que trabajaron con él lo tuvieron claro al realizar la mínima inversión económica, imitando libros existentes y probablemente pensando en una distribución local para las ferias castellanas. Fue probablemente esta manera de trabajar en la primera época de la imprenta en la Península lo que motivó la petición insistente a los Reyes Católicos de Privilegios de los impresión ${ }^{55}$.

Recibido: 28/04/2016 Aceptado: 27/06/2016

${ }^{55}$ Cfr. Fermín de los Reyes Gómez, «Con Privilegio: La exclusiva de edición del libro antiguo español», en Revista General de Información y Documentación 11-2 (2001), pp. 163-200. 
$\cos 8$

REFLEXIONES SOBRE EL LIBRO ILUSTRADO

DEL IMPRESOR FADRIQUE BIEL DE BASILEA

Resumen: Se estudia en este artículo la producción impresa ilustrada de la época incunable del impresor burgalés Fadrique Biel, Alemán de Basilea. La casi totalidad de sus libros con láminas en su interior han sido copiados de ejemplares procedentes de las prensas zaragozanas de los Hurus, y unos pocos imitan impresos franceses de finales del siglo xv. Posiblemente mantuvo una competencia desleal con los talleres que le sirvieron de inspiración. La innovación de los entalladores y cinceladores de la imprenta burgalesa es escasa, por lo que se pone en duda la originalidad de las láminas de la Comedia de Calisto y Melibea.

Palabras ClaVe: Libro ilustrado. Fadrique Biel de Basilea. Imprenta hispánica incunable.

\author{
Reflexions on the Picture Book \\ of the Printer Fadrique Biel of Basel
}

ABSTRACT: This article aims to study the illustrated print works produced by Fadrique Biel, Alemán de Basilea, printer of Burgos, during the time of the incunabula productions. Almost all of his books illustrated with engravings were copied from the presses of the Hurus, the printers in Zaragoza, and some of them imitate the French books printed in the late fifteenth century. Hence, he may have maintained an unfair competition with the printers that inspired him. The innovations advanced by the carvers and engravers of the printing houses in Burgos are poor, and as a consequence, the originality of the engravings in the Comedy of Calisto and Melibea printed by Fadrique de Basilea is here questioned.

KeYwords: Ilustrated Book. Fadrique Biel de Basilea. Hispanic Incunabula Printing. 